\title{
Introduction
}

\section{Educational inclusion: towards a social justice agenda?}

\author{
Bhopal, K and Shain, F (2014) \\ British Journal of Sociology of Education \\ Vol 35, no.5. Pages 645-649 | Published online: 21 Aug 2014 \\ https://doi.org/10.1080/01425692.2014.938937
}

Social justice and inclusion are complex and contested terms that feature prominently in current global and national education policy rhetoric. The latest Global Monitoring Report (UNESCO 2014) for example, assesses progress against the Education for All (EFA) goals ${ }^{1}$ that were established in 2000 with the aim of securing universal access for all children to basic education by 2015 . The EFA framework, along with the United Nations Millennium Development Goals (http://www.un.org/millenniumgoals/) is underpinned by a particular view of social justice as 'distributional justice' (Gewirtz 1998) and an assumption that the provision of standardized systems of teaching, learning and assessment to support 'the weakest learners' will bring about 'equality for all' (EFA 2014, i). However, as Connell (2012) has argued, social justice in education is not just about equality in the distribution of, or access to, an educational service, which is important, but 'social justice concerns the nature of the service itself, and its consequences for society through time' (681).

What Connell means is that the shape and direction of education is never neutral but is influenced and structured by dominant agendas and interests that shift over time to reinforce

\footnotetext{
${ }^{1}$ These are to: expand early childhood care and education; provide free and compulsory primary education for all; promote learning and life skills for young people and adults; increase adult literary by $50 \%$; achieve gender parity in education by 2005 , gender equality by 2015; improve the quality of education. Although UESCO's statistics show that the number of children out of school fell by almost a half between 1999 and 2011, by 2011, 57 million children were still out of school. In sub-Saharan Africa, 22\% of the region's primary school age population was still not in school by 2011 and by all accounts the targets are unlikely to be met by 2015 .
} 
and reproduce particular forms of privilege and inequality. In the last two decades, educational sociologists have mapped the various ways in which 'Western-centric' (Amin 2010) neoliberal policies have come to be both embedded and resisted within educational sectors - albeit unevenly across different locales and with different effects. As Ozga (2011, 307) notes, market mechanisms are displacing the State, services are being outsourced to hybrid public-private organisations, and there is an increasing devolution of responsibility for self-management, choice-making and the management of risk to individuals and families and away from State institutions. As transnational actors such as the World Bank, the International Monetary Fund (IMF) and the Organisation for Economic and Cooperative Development (OECD) increasingly (since the 1990s) set the agenda for regional and national education policies, questions emerge about the social justice implications of this direction of travel and the means by which it is being rolled out. Neoliberal policies are being promoted through the EFA framework and the policies of the World Bank as the ideal and only way of bringing economic prosperity to the poor and for driving up 'standards' in the context of Western economic decline.

Even before the onset of the Global Financial Crisis in 2008, it was clear that neoliberal policies had not delivered the promised economic growth and that income inequalities had increased (see for example International Labour Office and United Nations reports and analysis (Peck and Tickell 2002, Jessop 2002, Harvey 2005, Amin 2010). However, the austerity measures that have imposed large public spending cuts in countries such as Portugal, Spain, Ireland and Greece have further sharpened longstanding inequalities by hitting directly on the State's ability to deliver on equity. In England, for example, policy measures introduced since 2010, in the name of austerity, include the abolition of the Educational Maintenance Allowance - a grant of around $£ 30.00$ per week that was aimed at helping poorer 16 to 17 -year-olds to stay in education. This development has occurred alongside a tripling of higher education fees from $£ 3000$ to $£ 9000$ per annum creating new barriers in terms of access to higher education. Those most affected include poor, working class and minority ethnic young people with consequences for their chances of social mobility and future success in the labour market (Sutton Trust 2013).

It is against this background that this special issue of BJSE explores notions of inclusion and social justice in educational settings ranging from elementary schools to higher education. The nine contributions inevitably discuss only a selection of social justice and inclusion 
issues and all but one focus on education in the 'neoliberal heartlands' (Peck and Tickell 2002) of Western Europe, North America and Australia where market-oriented policies have been pursued relentlessly since the 1980s. Collectively, the papers explore policy, practice and pedagogical considerations covering different dimensions of (in)equality including disability, race, gender and class. They raise questions about what social justice and inclusion mean in educational systems that are dominated by competition, benchmarking and targetdriven accountability and how new forms of imperialism and colonisation both drive and are a product of market-driven reforms. The papers also point to the resources that teachers, pupils and parents (might) draw on to counter the negative impacts of market-oriented policies. Finally, a range of 'policy buzzwords' (Cornwall and Brock 2005) including 'participation', 'empowerment' and 'involvement' appear across several of the contributions. These terms, which speak ostensibly to social justice and inclusion agendas, are also critically considered in terms of what they mean in practice.

We turn now to a brief description of each paper in the issue.

Meshulam and Apple highlight the challenges involved in enacting social justice even in a school that has a history of fighting for it. They draw on the case study of a U.S. public elementary bilingual and multicultural school. Despite being a pioneer of an 'inclusive' antiracist curriculum, they find that under onslaught of neoliberal policies, the school has had to make concessions that serve paradoxically to reinforce the cultural domination, marginalization, and exclusion of its African American students. Konrad, Grant, Floch and Swenson, likewise, explore the mechanisms that serve to reproduce the unequal and racialised opportunity structure in the U.S. Their discussion of the closure, in 2013, of 50 out of the 54 Chicago public schools is framed by a 'critical spatial perspective' in which the closure of 'underperforming' schools is seen as counterproductive to the 'rights to the city'. Like Meshulam and Apple, Konrad, Grant, Floch and Swenson find African American students to be at the sharp end of the neoliberal restructuring policies. The authors conclude by calling for increased democratic participation from students, parents and community leaders who are involved in urban school systems on a national and international basis to resist these new forms of gentrification and colonisation.

Turning the emphasis to higher education, Gale and Hodge draw on Australia as a case study for exploring the 'policy effects' (Ball 1993) of current social inclusion policies within 
OECD nations. They argue that a new 'imaginary' has emerged in the 'Asian Century', about higher education's role in interrupting the declining advantage of OECD nations in the 'rapidly changing profile of the global economy'. This new imaginary supports an expansionist agenda that shows evidence of widening access to education; however, it fails to translate into a second order effect of challenging existing relations of domination and patterns of privilege. Staying with Australia and the OECD's role in the global governance of education, Seller, Lingard and Savage consider the ways in which social justice is being rearticulated as 'equity' in education. Examining mechanisms of national and global testing, such as the National Assessment Programme - Literacy and Numeracy (NAPLAN) and the Programme for International Student Assessment (PISA), they conclude that standardised systems of measurement and comparison 'have become central in contemporary education policy regimes and that this has weakened the influence of conceptual-discursive accounts of what constitutes social justice schooling'.

Taking up the EFA agenda and turning to issues of access and inclusion in secondary education in rural India, Kelly and Bhabha explore the gendered power dynamics that restrict poorer girls from benefiting from widened access to secondary education. Drawing on Connell's gender and power framework, the authors' question whether the Indian government's focus on extending education programmes to rural communities can deliver equal opportunities for girls. They assert that without challenging existing material inequalities, and the dominant cultural values and patriarchal frameworks than underpin family and education systems, the possibilities for a redistribution of opportunity are not only extremely limited but potential exists for further marginalisation based on gender, class and caste. Mac an Ghaill and Haywood explore what inclusion/exclusion means to a group of young British Pakistani and Bangladeshi men in English Schools who experience education against the backdrop of the U.S. inspired global 'war on terror'. Focusing their analysis on reconstructions of masculinity, class and the emergence of a schooling regime which operates through neoliberal policies, they note 'the increasing ambivalence surrounding race/ethnicity and the growing visibility of a neo-conservative nationalism that impels an absolute cultural (moral) difference, means that categories of same and other are moving into sharper distinction'.

With a focus on the United Kingdom, Veck critically considers austerity policies and approaches to understanding the education of disabled people in relation to the decline of 
community and the longing for its existence. Drawing on the work of Arendt and Bauman, he argues that, '...in a society where individuals are increasing indifferent to one another, addressing disability means defending community and its possibilities for generating and sustaining caring, responsive and inclusive relationships'. Keeping the focus on community, but moving to a discussion of adult learners, Busher, James, Piela and Palmer focus on learner identities in 'access to higher education' courses that are delivered in the further education sector in England. The students in their research study were marginalised by formal learning processes but were able to enhance their social and cultural capital by being active participants in their learning. They achieved this by working with teachers to form collaborative learning cultures through communities of practice.

Finally, drawing on a Critical Race Theory, D'Arcy focuses on the policy of Elective Home Education (EHE) for Traveller families in England. Her argument is that this apparently inclusive policy facilitates the exclusion of Traveller children. She challenges the dominant discourse which frames EHE as 'free choice' deriving from Travellers' mobility. Instead, D'arcy finds that the take-up of EHE is often linked to the experience of racism and discrimination so that families who are deeply committed to their child's education are forced to make the choice to home school their children.

The papers presented in this issue enable us to reflect on the establishment of neoliberalism, as the new global orthodoxy in the field of education and to begin to analyse what this means for social justice and inclusion. The papers raise possibilities for hope and resistance, drawing attention to established and successful attempts at democratic education or community organisation. However, they also expose ongoing tensions between recognition and redistribution as principles for social justice and the entrenchment, under current neoliberal systems of educational provision, of longstanding patterns of (racialised, classed and gendered) privilege and disadvantage that need to be highlighted and addressed.

Kalwant Bhopal and Farzana Shain

\section{References}

Amin, S. 2010. Ending the crisis of capitalism or ending capitalism?. Oxford: Pambazuka Press.

Connell, R. 2012. 'Just education.' Journal of Education Policy, 27 (5): 681-83. 
Cornwall, A., and Brock, C. 2005. 'What do buzzwords do for development policy? A critical look at 'participation', 'empowerment' and 'poverty reduction'.' Third World Quarterly 26 (7) 1043-1060.

Gewirtz, S. 1998. 'Conceptualizing social justice in education: Mapping the territory.' Journal of Education Policy 13. (4): 469-484.

Harvey, D. 2005. A brief history of neoliberalism. Oxford: Oxford University Press

Jessop, B. 2002 . 'Liberalism, neoliberalism, and urban governance: A state-theoretical perspective', Antipode, 34(3) p. 452-472.

Ozga, J. 2011. 'Governing Narratives: "Local” meanings and globalising education policy' Education Inquiry 2(2): 305-318.

Peck, J and Tickell, A. 'Neoliberalizing space.' Antipode 34.3 (2002): 380-404.

Sutton Trust. 2013. Advancing Access and Admissions. London: Sutton Trust.

UNESCO. 2014. Teaching and Learning: Achieving Quality for All. Education for All Global Monitoring Report, UNESCO. 